\title{
Information flow between revenue and stock exchanges: An empirical research on liner shipping companies
}

\author{
Abdullah Açık (D, Esra Baran Kasapoğlu (D), İlke Sezin Ayaz \\ Department of Maritime Business Administration, Maritime Faculty, Dokuz Eylül University, \\ Adatepe Neighbourhood, Doğuş Road, No: 207/O 35390, Tınaztepe Campus, Buca, İzmir, Turkey \\ abdullah.acik@deu.edu.tr; esra.baran@deu.edu.tr; ilke.ayaz@deu.edu.tr
}

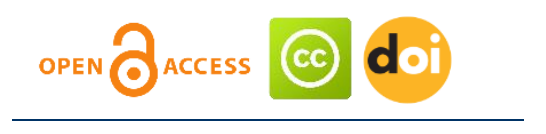

\section{Article history:}

Received: December 30, 2020

1st Revision: March 22, 2021

Accepted: April 20, 2021

\section{DOI:}

10.14254/jsdtl.2021.6-1.7

\begin{abstract}
The aim of this research is to test the volatility spillover between the stock values of the major liner shipping companies in the world and the freight indices measuring the freight revenues in the container market. The dataset in the study consists of 9 stock values of the top 10 biggest liner companies in 2018 and 3 container freight indices on weekly basis covering the period between 05.11.2010 and 06.07.2018. Volatility spillovers have been determined to some companies' stock values from some container freight indices, and the most influential freight index has been determined as New ConTex. Moreover, some volatility spillovers from some companies' stock values to freight indices have been also determined. These results suggest that some stock investors position their portfolios in the market according to the flow of information from freight indices while some investors position by following macro variables.
\end{abstract}

Keywords: volatility spillover, information flow, stock price, freight index, liner shipping.

\section{Introduction}

Considering the container transportation sector, the demand for this sector is derived demand, therefore, it is directly affected by the situation in the world economy. The variables that affect and show the situation in the world economy are macro variables. As a continuation of this mechanism, it can be said that macro variables also have a direct impact on the profitability of companies since they affect the demand for maritime transportation. These internal factors such as profitability and financial performance can affect stock values of liner companies either positively or negatively. In this context, it is inevitable for stock values of the liner companies to have a flow of information from indices indicating the revenue status in the market and from macroeconomic variables. At this point, in this study, the causality in variances among the stock prices of liner shipping companies entering the top 10 in the world and the freight indices used in the container freight market are examined. This method analyzes the volatility spillover between stock values and freight indices. Thus, it is aimed to determine whether

Corresponding author: Abdullah Açık

E-mail: abdullah.acik@deu.edu.tr 
there is a flow of information between the freight rates in the market, which is the main source of maritime companies, and stock values of the liner companies.

The dataset in the study consists of 9 stock values of the top 10 biggest liner companies in 2018 and 3 container freight indices. The included companies are APM Maersk, Hyundai Merchant Marine, Kawasaki Kisen Kaisha, Nippon Yusen Kaisha, Evergreen, Mitsui Osaka Shosen Kaisha, Orient Overseas, Yang Ming Marine Transport Corp. and Cosco. Mediterranean Shipping Co., CMA CGM and Pacific Int. Line are not included in the analysis since they are not trading in stock market. Also, Hapag-Lloyd cannot be included as the company has been trading in the market for relatively short time. The included freight indices are Shangai Containerized Freight Index, (SCFI), China Containerized Freight Index (CCFI) and New Contex (Container Ship Time Charter Assessment Index). The data set consists of weekly observations covering the period between 05.11.2010 and 06.07.2018. According to the results, volatility spillovers have been determined to some companies' stock values from some container freight indices, and the most influential freight index has been detected as New ConTex. There are some volatility spillovers from other freight indices as well. Moreover, some volatility spillovers from some companies' stock values to freight indices have been also determined. These results suggest that some stock investors position their portfolios in the market according to the flow of information from freight indices. Also it can be said that some stock investors are positioned in the stock market by following macro variables. It is thought that due to the delayed effects of macro variables to the maritime market, the results show some volatility spillovers from stock values to the freight indices. In addition, it is hoped that these results will help investors who are interested in the stocks of liner companies to be able to read the information flow correctly in the stock market. No studies on this topic have been identified in the literature, in this respect, it is hoped that an important contribution is made to the literature.

The remainder of the paper is organized as; the factors affecting the stock values are described in the first section; the general information about the liner shipping market is provided in the second section; the major freight indices in the liner shipping market are mentioned in the third section; the method used in the study is introduced in the fourth section; the results obtained from the analysis are presented in the fifth section; and finally, the conclusions are made in the last section.

\section{Factors effecting stock prices}

The determinants of stock prices can be categorized as internal and external factors. The internal factors can be regarded as company specific factors and the external factors are macroeconomic factors. There are several studies investigating the factors that affecting stock prices which concluded different results. While some studies found that company specific variables are major factors that affect stock prices, others stated that external factors related to economic conditions are the main influencing factors of stock prices.

In the external factors related literature, Nasseh and Strauss (2000) determined a significant relationship between stock prices and national and international macroeconomic variables (industrial production, short- and long-term interest rates etc.) in European economies. Muradoglu et al. (2001) investigate the relationship between stock returns and monetary variables in an emerging Turkish Stock Market. The interactions between economic indicators like industrial production, interest rate, exchange rate, oil prices etc. and stock prices in Greece are examined by Hondroyiannis and Papapetrou (2001). They stated that "changes in oil price can define stock price courses and its effect macroeconomic activity is negative". The study of Mahmood and Mohd Dinniah, (2007) concentrated the relationship between stock price and macroeconomics indicators such as inflation, output and exchange rates of six countries in Asian-Pacific region. Sunde and Sanderson (2009) reviewed the determinants of share price in Zimbabwe and concluded that economic and political factors are the major influential factors for the stock prices. Humpe and Macmillan (2009) examined the effect of macroeconomic variables in US and Japan and the findings revealed that US stock prices were positively affected by industrial production and negatively by consumer price index and the long interest rate. Japanese stock prices are positively related to industrial production and negatively to the money supply. Nisa and Nishat (2011) found that the macroeconomic indicators like GDP, interest rate, inflation and financial depth and internal factors like earnings per share and company size have significant relationship with the stock prices in Pakistan. Internal and external factors affecting stock market prices in Amman Stock Exchange are examined by Allahawiah and Al Amro (2012) and concluded that the most 
influential factor is inflation rate and the least one is the nature of firm. Maysami et al. (2005) investigate the relation between macroeconomic variables and the Sector Stock Indices unlike the other composite index related studies.

In the internal factors related literature, Sharif et al. (2015) only considered firm specific factors such as return on equity, book value per share, dividend per share, dividend yield, price earnings, and firm size in their study and they found that these variables are remarkable effective factors of stock prices in the Bahrain market. Sharma, S. (2011) found that there is a significant relation between market share price and accounting variables such as earning per share, dividend per share, book value per share in the Indian market. Uwuigbe et al. (2012) supported the positive interaction between financial performance of firms and the market value of stock prices in the Nigerian stock exchange market. The study findings of Gill et al. (2012) revealed that book value per share, earnings per share, dividend per share, price-earnings ratio, the CEO duality, and the internationality of the firm influence the variance of equity share prices in USA (NYSE). Aveh and Awunyo-Vitor (2017) examine the firm-specific determinants of stock prices on the Ghana Stock Exchange and results showed a positive remarkable interaction between ROE, earning per share (EPS), book value, market capitalization and market price of shares on the Ghana Stock Exchange. In the same study a remarkable negative interaction was determined between stock market prices and dividend yield.

Apart from studies affecting the values of stocks, a study examining the relationship between price bubbles in stocks in the maritime field was conducted by Açı et al. (2019). The authors firstly determined the price bubbles in the stock values of 8 of the world's top 10 container liner companies by GSADF (Generalized Sup Augmented Dickey-Fuller) method. Then, they examined the correlation between them by assigning a dummy variable to the days that were found to be price bubbles. They found significant correlations between stock values of some liner shipping companies whose prominent feature is that they are generally traded on the same stock exchange market. According to these results, it was revealed that not only the commercial performance of container companies, but also the stock exchange they are traded on have a significant effect on their stock returns.

As can be seen from these studies and findings, stock prices of firms are affected by both internal and external factors. In the next section, the general situation of liner shipping in the world is mentioned.

\section{Liner shipping companies in the world}

Liner shipping services play a central part in the global trading network which are an addition to the shipping industry, dating from the 1870s (Stopford, 2009). Container shipping is fundamental for global trade which is provided by regular liner shipping services including direct services and services that involve the transshipment of containers in hub ports (UNCTAD, 2018b).

The global container shipping sector which handles about $60 \%$ of seaborne merchandise trade in terms of value, demonstrated some developments leading to major market consolidation (through mergers and acquisitions or alliances) since 2016. Consolidation activities seen in 2016-2018 represents the industry's response to cope with the troublesome market situation encountered since the 2008 global economic crisis by cargo pooling, improving economies of scale and reducing operating costs (UNCTAD, 2018a).The major mergers and acquisitions in recent years including the merger of the Japanese container ship operator groups as "ONE" which is a joint venture developed between Nippon Yusen Kabushiki Kaisha, Mitsui Osaka Shosen Kaisha Lines and Kawasaki Kisen Kaisha on April, 2018 (Ocean-Insights, 2018). Cosco Shipping Holdings has provided all the requirements for its changeover of Orient Overseas International on June, 2018 (Sea Trade-Maritime, 2018). Hapag-Lloyd completed integration with the United Arab Shipping Company (UASC) on May, 2017 (World Maritime News, 2018). Maersk Line completed the acquisition of Hamburg Süd on November, 2017 (Maersk, 2018).

In January 2018, the top 15 container liner companies controlled almost $70 \%$ of all container transport capacity. 6 months later, in June 2018, the top 10 liner companies controlled almost the same (70 per cent) container fleet capacity (UNCTAD, 2018b). According to data obtained from Alphaliner, the global top 10 liner shipping companies are presented in Table 1. As stated by Alphaliner, these TEU capacity figures are consolidated. For instance, APM-Maersk includes Maersk Line, Hamburg Süd, Safmarine, MCC-Transport and Seago Line. Hapag-Lloyd integrates the previous UASC fleet capacity. 


\begin{tabular}{|c|c|c|c|}
\hline Rank & Liner Operator & TEU & $\begin{array}{l}\text { Market share } \\
\text { (percentage) }\end{array}$ \\
\hline 1 & APM Maersk & $4,043,653$ & $17.9 \%$ \\
\hline 2 & Mediterranean Shipping Co. & $3,251,177$ & $14.4 \%$ \\
\hline 3 & COSCO Group & $2,810,028$ & $12.4 \%$ \\
\hline 4 & CMA CGM & $2,646,479$ & $11.7 \%$ \\
\hline 5 & Hapag-Lloyd & $1,595,408$ & $7.1 \%$ \\
\hline 6 & ONE (Ocean Network Express) & $1,537,973$ & $6.8 \%$ \\
\hline 7 & Evergreen Line & $1,194,916$ & $5.3 \%$ \\
\hline 8 & Yang Ming Marine Transport Corp. & 627,519 & $2.8 \%$ \\
\hline 9 & PIL (Pacific Int. Line) & 417,346 & $1.8 \%$ \\
\hline 10 & Hyundai Merchant Marine & 415,063 & $1.8 \%$ \\
\hline
\end{tabular}

Source: Alphaliner (2018).

According to UNCTAD report, the container freight market developed significantly after a difficult market environment in 2016. In 2017, the global container demand increased by 6.4 per cent and global supply of container ship-carrying capacity increased by 3.8 percent. A better balance in supply and demand by a higher demand is the main factor for increased freight rates in container markets. The container transport industry reached approximately a total profit of $\$ 7$ billion with a significant increase by the end of 2017. According to financial performance of shipping lines in 2017, CMA CGM experienced the best operating outcomes followed by Maersk Line and Hapag-Lloyd (UNCTAD, 2018b).

\section{Freight indices in container transport}

Various indices are used in maritime transport to monitor the current situation, market behavior and possible future movements of the market. Also, these indices are used for future estimations by analyzing with various econometrics methods (Karamperidis et al., 2013). Different freight indices are developed for different maritime transport markets. For dry bulk cargo transportation, the major freight indices are Baltic Dry Index (BDI), Baltic Capesize Index (BCI), Baltic Supramax Index (BSI) and Baltic Panamax Index (BPI). For liquid bulk transportation, the major indices are Baltic Dirty Tanker Index (BDTI) and Baltic Clean Tanker Index (BCTI). And lastly, for the container transport market, the major indices are Shangai Containerized Freight Index, (SCFI), China Containerized Freight Index (CCFI) and New Contex (Container Ship Time Charter Assessment Index). Considering the scope of our research, the indices related to the container market are mentioned below.

Shanghai Shipping Exchange (SSE) is the first state-level shipping exchange in China. In November 1996, The Ministry of Transport and Shanghai Municipal People's Government are founded SSE with the approval of the State Council (Shanghai Shipping Exchange, 2018a).

The spot freight rates of export container transport market from Shanghai are represented by The Shanghai (Export) Containerized Freight Index (SCFI) that involves both spot rates of 15 different maritime routes and the overall index. The freight data for indexes are obtained from the 20 contributor of liner shipping companies and 17 contributor of shippers/freight forwarders (Shanghai Shipping Exchange, 2018b). It is a highly referred indicator which is used to examine the health of shipping trade (Flexport Blog, 2018).

China (Export) Containerized Freight Index (CCFI) represents China's country-wide export container trade by the freight rates of individual trade routes showing the increases and decreases of the maritime trade lanes. 22 maritime companies with high international prestige and big market shares provide the freight rate information voluntarily. CCFI objectively provides essential information related to container transport market for decision-makers of several maritime and trade enterprises as well as the governmental agencies. It is said that CCFI is regarded as the world second influential freight index following the Baltic Dry Bulk Freight Index (Shanghai Shipping Exchange, 2018c). While SCFI targets at the spot rates from Shanghai to other ports included in the index, CCFI targets both spot and contractual rates of China's export container transport market. So CCCFI is more representative, extensive and macroeconomic than SCFI's narrower scope (Shanghai Shipping Exchange, 2018d; Crucial Perspective, 2018). 
Container Ship Time Charter Assessment Index (CTEXIDEX - New ConTex) which is company independent index representing the container charter rate for six types of containers according to their size categories. It is published by the Hamburg Shipbrokers' Association since 2007 based on information provided by independent shipbroker panelists (Lloyds List, 2018; Fonasba, 2018). It provides accurate, neutral, transparent and understandable overview of the container market situation by the expertise of shipbroker panelists (Verband Hamburger und Bremer Schiffsmakle, 2018). In the next section of the study, the method we use to investigate the volatility transmissions between variables is introduced.

\section{Methodology}

Many methods are used in the analysis of econometric relations between variables. These methods vary according to the purpose of the study, the dataset used, the theory based on and the findings to be obtained. Analyzes that test whether one variable is the cause of another, based on historical values of the variables, are called causality analysis and are widely used. These tests have been improved and diversified over time. Some are composed of linear models while others are non-linear models as the relationships between variables are almost impossible to be linear in real life.

The causality in variance is one of the most widely used methods and it is able to detect volatility transmission between two financial variables (Bayat et al., 2015). Also it is important for financial variables since volatility transmission between financial markets can be indicated by this method (Koseoglu \& Cevik, 2013). It has been first implemented by the process introduced by Cheung and $\mathrm{Ng}$ (1996). The test is based on the cross correlation function (CCF) of squared univariate GARCH residual estimates. However, in small samples, remarkable oversizing may cause problems in corresponding CCF-based Portmanteau test if the volatility types are leptokurtic (Nouira et al., 2019). In order to improve this deficiency, Hafner and Herwatz (2006) introduced a new method to test volatility spillover between variables. This method considers Lagrange multiplier (LM) principle. Also Monte Carlo simulation technique was used and robustness of the LM approach against indicated deficiency was proved (Nazlioglu et al., 2013).

The volatility spillovers between some container freight indices and stock values of some container liners were tested by causality in variance test proposed by Hafner and Herwartz (2006). The data set is introduced and the findings obtained from the analysis are presented in the next section.

\section{Findings and results}

Firstly, the series are converted to log return series by using $\ln \left(v_{t} / v_{t}-1\right)$ where $v_{t}$ is value of the related index value or stock price on week t and vt-1 is value of the related index value or stock price on week t-1. Descriptive statistics of the converted variables are showed in Table 2.

\begin{tabular}{lcccccccccccc}
\multicolumn{1}{l}{ Table 2: Descriptive statistics of the return variables } \\
\hline & CTEX & CHI. & SHA. & HYU. & KAW. & MAER. & MITS. & NIP. & ORI. & COSC. & EVG. & YAN. \\
\hline Mean & 0,000 & $-0,001$ & $-0,001$ & $-0,010$ & $-0,001$ & $-0,005$ & $-0,002$ & -0.001 & 0,000 & -0.004 & -0.001 & -0.004 \\
Med. & $-0,001$ & $-0,001$ & $-0,012$ & $-0,012$ & $-0,003$ & 0,002 & $-0,002$ & 0.000 & -0.00 & 0.000 & -0.001 & -0.004 \\
Max. & 0,064 & 0,092 & 0,405 & 0,433 & 0,128 & 0,096 & 0,124 & 0.123 & 0.208 & 0.610 & 0.153 & 0.161 \\
Min. & $-0,052$ & $-0,079$ & $-0,168$ & $-0,267$ & $-0,156$ & $-1,464$ & $-0,136$ & -0.116 & -0.289 & -0.500 & -0.123 & -0.221 \\
Std. Dev. & 0,013 & 0,017 & 0,069 & 0,065 & 0,042 & 0,081 & 0,043 & 0.039 & 0.041 & 0.121 & 0.035 & 0.040 \\
Skew. & 0,923 & 0,475 & 2,294 & 0,955 & $-0,175$ & $-14,845$ & $-0,086$ & -0.139 & -0.492 & 0.388 & 0.312 & -0.230 \\
Kurtosis & 8,394 & 6,574 & 12,285 & 9,412 & 3,778 & 268,400 & 3,570 & 3.366 & 10.8 & 8.41 & 5.08 & 6.2 \\
J-B & 541.6 & 227.9 & 1787.8 & 745.9 & 12.1 & 1188648 & 5.9 & 3.52 & 1045.7 & -1.65 & 78.0 & 180.6 \\
Prob. & 0.00 & 0.00 & 0.00 & 0.00 & 0.00 & 0.00 & 0.05 & 0.17 & 0.00 & 5.92 & 0.00 & 0.00 \\
Obs. & 400 & 400 & 400 & 400 & 400 & 400 & 400 & 400 & 400 & 400 & 397 & 397 \\
\hline
\end{tabular}

Source: Investing (2018); Bloomberg (2018).

The data set is formed by weekly observations covering the period between 05.112010 and 06.07.2018. The data belonging to Evergreen and Yang Ming stocks are 3 observations less from the others due to the loss frequencies. When the skewness values of the stock variables are examined, it can be seen that Hyundai, Evergreen, Yang Ming and Cosco variables have positive values which indicates that the positive news impacts are higher in these series, whereas the remained stocks have negative 
values which indicates that impact of negative news are higher. All of the three container freight indices have positive values, indicating that the positive news impacts are higher in the covered period. Also, the extreme Skewness and Kurtosis values of the Maersk variable are interpreted as containing an outlier. In this direction, two separate tests are performed in the causality analysis with and without the outlier.

In the examination, a large outlier of Maersk stock value has been determined and extracted. Because the value in the series decreased from 33 thousand to 7 thousand at one-time unit and it distorted the results.

The correlation matrix between the log return states of all variables is presented in Table 3 . While some variables show high correlations, there is no correlation between some variables. The table also includes the stock markets where the stocks are traded in. The fact that highly correlated relations of the stocks are generally occurred in the same stock market is a natural result of being affected by the same macroeconomic variables.

\begin{tabular}{|c|c|c|c|c|c|c|c|c|c|c|c|c|c|}
\hline Markets & Variables & CT. & CH. & SH. & HY. & KW. & MA.. & MI. & NI. & OR. & YA. & EV. & CO. \\
\hline & CTEX & 1.00 & & & & & & & & & & & \\
\hline & CHINA & -0.01 & 1.00 & & & & & & & & & & \\
\hline & SHAN. & -0.04 & -0.06 & 1.00 & & & & & & & & & \\
\hline Seoul & HYUN. & 0.04 & 0.06 & 0.05 & 1.00 & & & & & & & & \\
\hline Tokyo & KAWA. & 0.03 & 0.02 & 0.01 & 0.07 & 1.00 & & & & & & & \\
\hline Copenhagen & MAER. & 0.01 & 0.04 & 0.06 & 0.10 & 0.25 & 1.00 & & & & & & \\
\hline Tokyo & MITSUI & 0.00 & 0.01 & -0.07 & 0.07 & 0.79 & 0.23 & 1.00 & & & & & \\
\hline Tokyo & NIPPON & -0.02 & 0.00 & -0.02 & 0.12 & 0.77 & 0.25 & 0.86 & 1.00 & & & & \\
\hline Hong Kong & ORIENT & -0.01 & 0.04 & 0.06 & 0.22 & 0.35 & 0.19 & 0.36 & 0.32 & 1.00 & & & \\
\hline Taiwan & YANG & -0.06 & -0.03 & 0.04 & 0.05 & 0.14 & 0.07 & 0.10 & 0.08 & 0.13 & 1.00 & & \\
\hline Taiwan & EVER. & -0.07 & 0.02 & 0.00 & 0.07 & 0.09 & 0.06 & 0.05 & 0.02 & 0.07 & 0.72 & 1.00 & \\
\hline Hong Kong & COSC. & 0.13 & -0.00 & -0.06 & 0.14 & 0.15 & 0.08 & 0.16 & 0.14 & 0.25 & 0.08 & 0.07 & 1.00 \\
\hline
\end{tabular}

The results obtained from the analysis are presented in Table 4. For Maersk company, analyzes were applied both with normal data and with outlier extracted data. Results have been found suitable to evaluate on the basis of separating freight indices. When the volatility spillovers from freight indices to stocks is examined firstly in accordance with the basic hypothesis of the study, it is determined that there are spillovers from the CTEXIDEX index to stocks of Hyundai, Kawasaki, Nippon, Evergreen and Cosco companies. When the SHSPSCFI index is examined, volatility spillovers from this index to stocks of Hyundai and Nippon companies are spotted. The last container freight index is the SHSPCCFI, and volatility spillovers from this index to stock prices of Maersk, Hyundai and Nippon companies are also confirmed.

As a result of the analysis, volatility spillovers from stock prices to freight indices are also determined. Accordingly, volatility spillovers from stock prices of Mitsui, Orient, Nippon, Yang Ming and Cosco companies to CTEXIDEX are detected. In addition, there is also spillover from Mitsui to SHSPCCFI. As is seen, volatility spillovers are detected in both directions between CTEX and stock values of the Nippon and Cosco companies.

\begin{tabular}{|c|c|c|c|c|c|c|}
\hline \multirow[b]{2}{*}{ COMPANIES } & \multicolumn{2}{|c|}{ CTEX } & \multicolumn{2}{|c|}{ SHANGAI } & \multicolumn{2}{|c|}{ CHINA } \\
\hline & SE to IN & IN to SE & SE to IN & IN to SE & SE to IN & IN to SE \\
\hline Maersk & $3.02[0.22]$ & $2.48[0.28]$ & 0.18 [0.91] & $2.25[0.32]$ & $1.18[0.55]$ & $4.46[0.10]$ \\
\hline Maersk ${ }^{* *}$ & $0.36[0.83]$ & $0.40[0.81]$ & 0.72 [0.69] & $1.59[0.45]$ & $2.02[0.36]$ & $7.09[0.02]^{*}$ \\
\hline Mitsui & $5.18[0.07]^{*}$ & $2.06[0.35]$ & $2.35[0.30]$ & $2.58[0.27]$ & $5.41[0.06]^{*}$ & $1.92[0.38]$ \\
\hline Orient & $5.86[0.05]^{*}$ & $1.49[0.47]$ & $2.01[0.36]$ & $1.63[0.44]$ & $2.36[0.30]$ & $0.86[0.65]$ \\
\hline Hyundai & $3.83[0.14]$ & $4.90[0.08]^{*}$ & $0.69[0.70]$ & $10.3[0.00]^{*}$ & $1.47[0.47]$ & $18.3[0.00]^{*}$ \\
\hline Kawasaki & $3.14[0.20]$ & $5.13[0.07]^{*}$ & $1.22[0.54]$ & $3.02[0.22]$ & $1.48[0.47]$ & $3.10[0.21]$ \\
\hline Nippon & $6.00[0.04]^{*}$ & $8.23[0.01]^{*}$ & 3.30 [0.19] & $5.97[0.05]^{*}$ & $3.68[0.15]$ & $5.17[0.07]^{*}$ \\
\hline Evergreen & $0.66[0.71]$ & $8.76[0.01]^{*}$ & $1.63[0.44]$ & $0.92[0.63]$ & $2.83[0.24]$ & $2.92[0.23]$ \\
\hline Yang Ming & $60.2[0.00]^{*}$ & $1.50[0.47]$ & $0.33[0.84]$ & $0.28[0.86]$ & $1.59[0.45]$ & $0.80[0.66]$ \\
\hline Cosco & $9.97[0.00]^{*}$ & $20.8[0.00]^{*}$ & $0.95[0.62]$ & $1.93[0.38]$ & $1.56[0.45]$ & $0.27[0.87]$ \\
\hline
\end{tabular}

Note: *Significant relationship, ${ }^{* *}$ Model estimated without outlier. 


\section{Conclusions}

We investigated volatility spillover between container freight indices and stock exchanges of selected liner shipping companies that are positioned in the highest levels in the world. One of the most significant determinants of the values of the transport companies is their financial performance. Of course, this performance is in line with the freight levels in the market. Therefore, it is inevitable that the stock values of container companies interact with the container freight indices. However, it is difficult to generate a linear pattern between these variables since there are many factors that affect both. In this respect, the methods that examine the causality between the variances are more appropriate and enable to identify the information flow between variables. In addition, the lack of a study examining the similar relationship in the literature constitutes a motivation for this study.

The data set consists of weekly observations covering the period between 5 November 2010 and 6 July 2018. The stock values of the liner shipping companies are selected form top 10 liners in the world. According to the results obtained, there are volatility spillovers from the CTEX index to the stock values of Hyundai, Kawasaki, Nippon, Evergreen and Cosco companies. There are also significant volatility spillovers from SHANGAI index to stock values but the number of companies is less. The effected companies are Hyundai and Nippon companies. And lastly, Maersk is added to these companies in the CHINA index. These results also reveal that; it can be said that the effects of investors' behaviors are determinant on the volatility spillover from the container indices to stock prices. For instance, investors who invest in stocks of liner companies such as Hyundai, Kawasaki, Nippon and Evergreen follow the CTEX index and form their stock portfolios according to the information gained from this index. Investors follow the revenues of the companies in the freight market and cause the prices of stocks to be shaped according to the freight index by positioning in the market.

On the other hand, there are also volatility spillovers from stock values to container freight indices. There are volatility spillovers from stock values of the Mitsui, Orient, Nippon, Yang Ming and Cosco companies to the CTEX index. While a volatility spillover to the SHANGAI index cannot be detected, a volatility spillover is found from the Mitsui company to the CHINA index. At first glance it can be considered as theoretically insignificant. This may be due to the fact that stock values are also indicators affected by macroeconomic variables. Negative or positive macroeconomic changes are reflected in the stocks first and then a volatility spillover occurs since there is a demand increase or decrease in transportation activities.

From here, it can be said that while stock investors of the companies such as Hyundai, Kawasaki, Evergreen and Maersk act according to the information they received from the container freight indices, stock investors of the companies such as Mitsui, Orient and Yang Ming act according to the information they received from the macro variables. Investors of Nippon and Cosco companies follow both of the macro and the freight variables, and act according to both of the information sources. Investors positioning according to macro variables seems logical, but still needs to be tested. Further studies may reach more consistent results by including these likely macro variables in the analysis. Similar relations can also be examined in other markets such as dry bulk market, tanker market and general cargo market.

It is hoped that these results define the movements of stock traders of liner companies in the current market and that they will be able to take more profitable positions by adjusting the next investment strategies in the light of these results.

\section{Citation information}

Açık, A., Baran Kasapoğlu, E., \& Ayaz, I. S. (2021). Information flow between revenue and stock exchanges: An empirical research on liner shipping companies. Journal of Sustainable Development of Transport and Logistics, 6(1), 81-89. doi:10.14254/jsdtl.2021.6-1.7.

\section{References}

Açlk, A., Baran, E. \& Ayaz, İ. S. (2019). Co-Movements of Price Bubbles in Stock Values of Global Liner Shipping Companies. Eurasian Journal of Researches in Social and Economics (EJRSE), 6(3), 42-50.

Allahawiah, S. \& Al Amro, S. (2012). Factors Affecting Stock Market Prices in Amman Stock Exchange: A Survey Study. European Journal of Business and Management, 4(4), 236-245. 
Alphaliner (2018). TOP 100. Retrieved from https://alphaliner.axsmarine.com, 03.10.2018.

APM Maersk. Retrieved from https://www.maersk.com/en/news/2017/11/30/ml-final-regulatoryapproval-hamburg-sud (Accessed 03 October 2018).

Aveh, F. K. \& Awunyo-Vitor, D. (2017). Firm-Specific Determinants of Stock Prices in An Emerging Capital Market: Evidence from Ghana Stock Exchange. Cogent Economics \& Finance, 5(1), 1-11. doi:10.1080/23322039.2017.1339385.

Bayat, T., Nazlioglu, S. \& Kayhan, S. (2015). Exchange Rate and Oil Price Interactions in Transition Economies: Czech Republic, Hungary and Poland. Panoeconomicus, 62(3), 267-285. doi:10.2298/PAN1503267B.

Bloomberg (2018, July 18). Container Freight Indices. https://www.bloomberg.com/professional/solution/bloomberg-terminal/.

Cheung, Y. W. \& Ng, L. K. (1996). A Causality-in-Variance Test and Its Application to Financial Market Prices. Journal of Econometrics, 72(1), 33-48. doi: 10.1016/0304-4076(94)01714-X.

Crucial Perspective (2018). Retrieved from https://crucialperspective.com/container-freight-ratesmonitor-week-13-of-2017, 26.09.2018.

Flexport Blog (2018). Retrieved from https://www.flexport.com/blog/shanghai-containerized-freightindex-scfi-history/, 26.09.2018.

Fonasba (2018). https://www.fonasba.com/wp-content/uploads/2012/10/New-Contex-Presentation.pdf, 26.09.2018.

Gill, A., Biger, N. \& Mathur, N. (2012). Determinants of Equity Share Prices: Evidence from American Firms. International Research Journal of Finance and Economics, 90(90), 176-192.

Hafner, C. M. \& Herwartz, H. (2006). A lagrange multiplier test for causality in variance. Economics Letters, 93(1), 137-141. doi: 10.1016/j.econlet.2006.04.008.

Hondroyiannis G. \& Papapetrou E. (2001). Macroeconomic Influences on The Stock Market. Journal of Economics and Finance, 25(1), 33-49. doi: 10.1007/BF02759685.

Humpe, A. \& Macmillan, P. (2009). Can Macroeconomic Variables Explain Long-Term Stock Market Movements? A Comparison of the US and Japan. Applied Financial Economics, 19(2), 111-119. doi: 10.1080/09603100701748956.

Investing (2018, October 18). Stock Prices of the Liner Companies. https://tr.investing.com/stockscreener/?sp=country::63|sector::a|industry::a|equityType::a\%3Ceq_market_cap;1.

Karamperidis, S., Jackson, E. \& Mangan, J. (2013). The Use of Indices in The Maritime Transport Sector. Maritime Policy \& Management, 40(4), 339-350. Doi: 10.1080/03088839.2013.776182.

Koseoglu, S. D., \& Cevik, E. I. (2013). Testing for Causality in Mean and Variance Between the Stock Market and The Foreign Exchange Market: An Application to the Major Central and Eastern European Countries. Finance a Uver, 63(1), 65-86.

Lloyds List (2018). from https://lloydslist.maritimeintelligence.informa.com/markets/containers/data-hub/data-hub-newcontex, 26.09.2018.

Mahmood, W. M. \& Mohd Dinniah, N. (2007). Stock Returns and Macroeconomic Influences: Evidence from the Six Asian-Pacific Countries. Financial Economics and Futures Market Research Paper, 1-21. doi: 10.2139/ssrn.995108.

Maersk (2018). Retrieved from www.maersk.com, 03.10.2018.

Maysami, R. C., Howe, L. C. \& Rahmat, M. A. (2005). Relationship Between Macroeconomic Variables and Stock Market Indices: Cointegration Evidence from Stock Exchange of Singapore's All-S Sector Indices. Jurnal Pengurusan (UKM Journal of Management), 24, 47-77.

Muradoglu G., Metin K. \& Argae R. (2001). Is There a Long-Run Relationship Between Stock Returns And Monetary Variables: Evidence from An Emerging Market?. Applied Financial Economics, 7(6), 641-649. doi: 10.1080/09603100110094411.

Nasseh, A. \& Strauss, J. (2000). Stock Prices and Domestic and International Macroeconomic Activity: A Cointegration Approach. The Quarterly Review of Economics and Finance, 40(2), 229-245. doi: 10.1016/S1062-9769(99)00054-X.

Nazlioglu, S., Erdem, C. \& Soytas, U. (2013). Volatility Spillover Between Oil and Agricultural Commodity Markets. Energy Economics, 36, 658-665. doi: 10.1016/j.eneco.2012.11.009. 
Nisa, M. N. \& Nishat, M. (2011). The Determinants of Stock Prices in Pakistan. Asian Economic and Financial Review, 1(4), 276-291.

Nouira R., Amor T.H. \& Rault C. (2019). Oil Price Fluctuations and Exchange Rate Dynamics in the MENA Region: Evidence from Non-Causality-In-Variance and Asymmetric Non-Causality Tests. Quarterly Review of Economics and Finance, 73(C), 159-171. doi: 10.1016/j.qref.2018.07.011.

Ocean-Insights (2018). Retrieved from https://www.ocean-insights.com/liner-news/ocean-networkexpress/, 03.10.2018.

Sea Trade-Maritime (2018). Retrieved from http://www.seatrade-maritime.com/news/asia/coscotakeover-of-oocl-cleared-for-completion.html, 03.10.2018.

Shanghai Shipping Exchange (2018b). Retrieved from http://en.sse.net.cn/brief/function0303.jsp, 26.09.2018.

Shanghai Shipping Exchange (2018a). Retrieved from http://en.sse.net.cn/brief/introen.jsp, 26.09.2018.

Shanghai Shipping Exchange (2018c). Retrieved http://en.sse.net.cn/indices/introduction_ccfi_new.jsp, 26.09.2018.

Shanghai Shipping Exchange (2018d) Retrieved from https://en.sse.net.cn/indices/fqaennew.jsp, 26.09.2018.

Sharif, T., Purohit, H. \& Pillai, R. (2015). Analysis of Factors Affecting Share Prices: The Case of Bahrain Stock Exchange. International Journal of Economics and Finance, 7(3), 207-216. doi: 10.5539/ijef.v7n3p207.

Sharma, S. (2011). Determinants of Equity Share Prices in India. Researchers World, 2(4), 51-60.

Stopford, M. (2009). Maritime economics 3rd ed., Routledge, London.

Sunde, T. \& Sanderson, A. (2009). A Review of the Determinants of Share Prices. Journal of Social Sciences, 5(3): 188-192. doi: 10.3844/jssp.2009.188.192.

UNCTAD (2018a). Market consolidation in container shipping: What next?. UN.

UNCTAD (2018b). Review of maritime transport 2018. UN.

Uwuigbe, U., Olusegun, 0. \& Agu, G. (2012). An Assessment of The Determinants of Share Price in Nigeria: A Study of Selected Listed Firms. Acta Universitatis Danubius, 8(6), 78-88.

Verband Hamburger und Bremer Schiffsmakle (2018). Retrieved from https://www.vhbs.de/index.php?id=28\&L=1, 26.09.2018.

World Maritime News (2018). Retrieved from https://worldmaritimenews.com/archives/236677/hapaglloyd-completes-integration-of-uasc/, 03.10.2018.

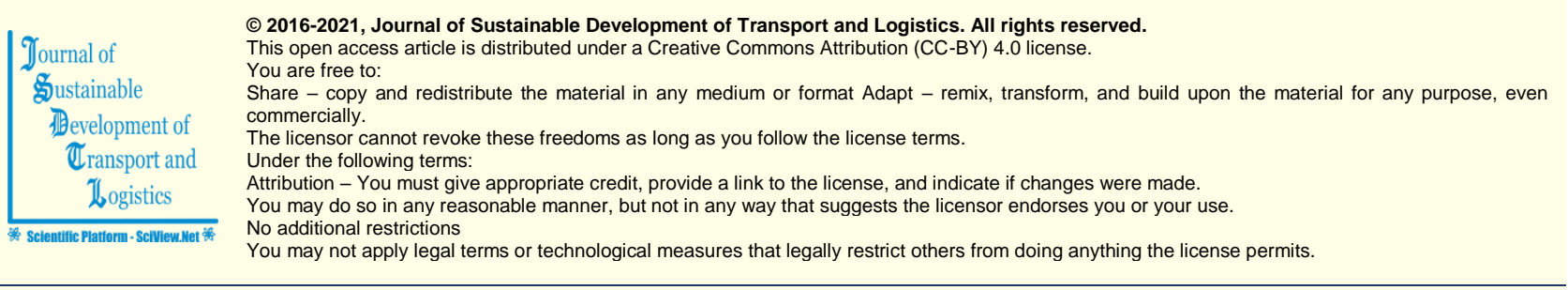

Journal of Sustainable Development of Transport and Logistics (ISSN: 2520-2979) is published by Scientific Publishing House "CSR",

Poland, EU and Scientific Publishing House "SciView", Poland, EU

Publishing with JSDTL ensures:

- Immediate, universal access to your article on publication

- High visibility and discoverability via the JSDTL website

- Rapid publication

- Guaranteed legacy preservation of your article

- Discounts and waivers for authors in developing regions

Submit your manuscript to a JSDTL at https://jsdtl.sciview.net/ or submit.jsdt|@sciview.net 